\title{
Database for content of mercury in Polish brown coal
}

\author{
Krzysztof Jastrząb * \\ Institute for Chemical Processing of Coal, Zamkowa 1 Str., 41-803 Zabrze, Poland
}

\begin{abstract}
Poland is rated among the countries with largest level of mercury emission in Europe. According to information provided by the National Centre for Balancing and Management of Emissions (KOBiZE) more than 10.5 tons of mercury and its compounds were emitted into the atmosphere in 2015 from the area of Poland. Within the scope of the BazaHg project lasting from 2014 to 2015 and co-financed from the National Centre of Research and Development (NCBiR) a database was set up with specification of mercury content in Polish hard steam coal, coking coal and brown coal (lignite) grades. With regard to domestic brown coal the database comprises information on coal grades from Brown Coal Mines of 'Bełchatów', 'Adamów', 'Turów' and 'Sieniawa'. Currently the database contains 130 records with parameters of brown coal, where each record stands for technical analysis (content of moisture, ash and volatile particles), elemental analysis (CHNS), content of chlorine and mercury as well as net calorific value and combustion heat. Content of mercury in samples of brown coal grades under test ranged from 44 to $985 \mu \mathrm{g}$ of $\mathrm{Hg} / \mathrm{kg}$ with the average level of $345 \mu \mathrm{g}$ of $\mathrm{Hg} / \mathrm{kg}$. The established database makes up a reliable and trustworthy source of information about content of mercury in Polish fossils. The foregoing details completed with information about consumption of coal by individual electric power stations and multiplied by appropriate emission coefficients may serve as the background to establish loads of mercury emitted into atmosphere from individual stations and by the entire sector of power engineering in total. It will also enable Polish central organizations and individual business entities to implement reasonable policy with respect of mercury emission into atmosphere.
\end{abstract}

\section{Introduction}

In August 2017 the so called Mercury Convention, also referred to a Convention from Minamata came into effect. The Convention, signed by Poland in September 2014, is aimed at comprehensive protection of environment and human health against release of mercury into atmosphere, water and earth. The regulations of the agreement govern issues associated with production of that metal, trading with mercury-containing products and application of mercury to products and industrial processes. In addition, the convention establishes rules

\footnotetext{
* Corresponding author: kjastrzab@ichpw.pl
} 
for handling and disposal of mercury-containing wastes in the manner that is safe for natural environment, implementation of appropriate methods for storage of mercury as well as deals with issues related to reclamation of areas polluted with that metal. The subsequent legislative document that Poland has undertaken to obey is the Directive 2010/75EU of the European Parliament and of the Council on industrial emissions (integrated pollution prevention and control), so called IED Directive that is effective from 2010. On $17^{\text {th }}$ August the document called Best Available Techniques (BAT) Reference Document for Large Combustion Plants, referred commonly as BAT Conclusions for Large Combustion Plants (LCP) was published in the Official Journal of European Union. The both documents impose really tough requirements to the permissible concentration of released pollutants and specify Best Available Techniques (BAT) necessary to keep the emission levels below the permissible limits.

Introduction of new legislative documents is particularly important since Poland is rated among countries with levels of mercury emission in Europe. The most recent survey carried out by the National Centre for Balancing and Management of Emissions (KOBiZE) revealed that emission of mercury from industrial processes and combustion of fossils on the area of Poland amounted in 2015 to $10,576 \mathrm{~kg}$. Shares of individual sectors of the national economy in emission of mercury into atmosphere are depicted in Fig. 1. The breakdown of mercury emission as shown in the diagram is caused by the fact that power generation by Polish plants is predominantly based on combustion of hard and brown coal with substantial contribution from extensive industry of building materials. citation.

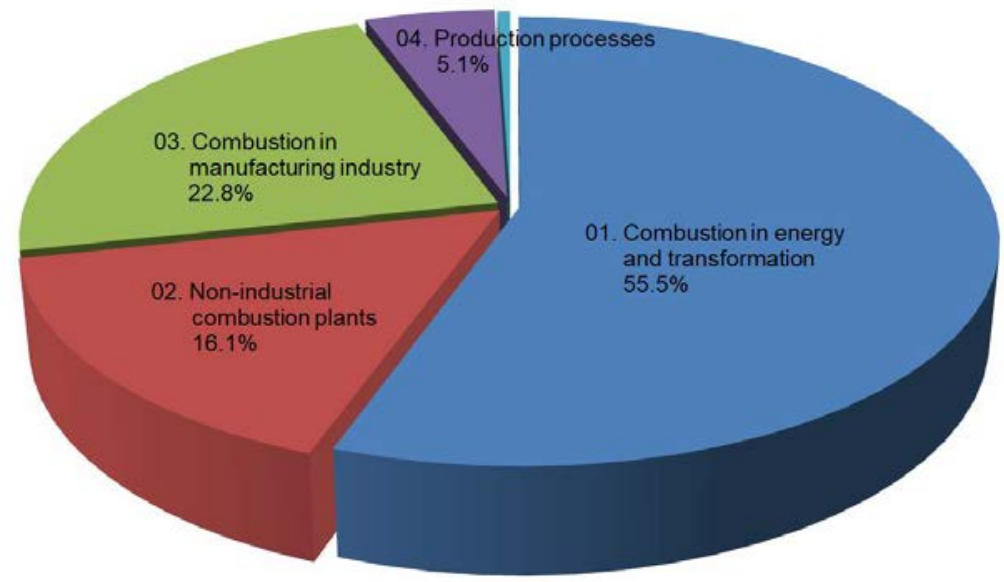

Fig. 1. Shares of sectors of the national economy in emission of mercury into atmosphere [1].

The balance presented herein indicates that the highest rates of mercury emission into atmosphere fall to the sector of power generation and conversion. Considerable portion of that emission is owed to power plants fuelled with brown coal (lignite) since these plants are rated among the largest ones in Europe with the total installed power of 9,220.5 MW at the end of 1st Q of 2015, which makes up 23.5\% of total power available from all domestic electric power as well as heat and power plants. Only during the 1st half of 2015 the power plants fuelled with brown coal generated 13,518 GWh of energy. Unfortunately, such levels of power generation need huge consumption of brown coal. For long years production of these coal grades has been being maintained at the level of 60 million tons per year, which is currently only slightly less that than total production of hard coal. Only during first six months of 2015 as much as 31.6 tons of brown coal were mined with the largest share of 
the Brown Coal Mine (KWB) 'Bełchatów' amounting to more than 21 million tons, which makes $67.8 \%$ of total production of brown coal within the country. The shares of other open-pit mines in total production of brown coal were distributed between KWB Konin (14.2\% /4.5 M tons), KWB Turów (11.1\% /3.5 M ton) and KWB Adamów (6.3\% /2.0 M ton).

Unfortunately, high consumption of brown coal always entails substantial emission of mercury and its compounds. First and foremost such emission levels result from high content of mercury in such a fossil like brown coal but lack of specialized systems or plants designed for mitigation of mercury emission into atmosphere is also quite important. Although some attempts to remove mercury from flue gas have already been undertaken at experimental plants operated at Electric Power Plant in Bełchatów (in collaboration between Polish Power Engineering Group (PGE) and Technical University of Łódź) and at 'Łaziska' Power Plant (jointly by Tauron, AGH University of Technology from Cracow and the Institute for Chemical Processing of Coal (IChPW) from Zabrze) but these studies are still on the level of tests.

The amount of mercury emitted into the atmosphere is mostly dependent on its content in fossils - hard and brown coal grades. It is estimated that the coefficient of mercury emission associated with combustion of brown coal is $0.15 \mathrm{~g} \mathrm{Hg} / \mathrm{Mg}$, which makes $9.0 \mu \mathrm{g}$ $\mathrm{Hg} / \mathrm{MJ}$ [3]. Thus, the rough emission of mercury from a typical Polish power plant ranges from 52 to $57 \mathrm{~kg}$ of $\mathrm{Hg}$ per year [4]. According to the practice of recent years the content of mercury is determined in fossils and the results from obtained from investigation of mercury content in coal grades mined worldwide [4-9] indicated that content of that element ranges from 20 to $1400 \mu \mathrm{g} / \mathrm{kg}$. The lowest content of mercury was found in Japanese coal grades (30 to $100 \mu \mathrm{g} / \mathrm{kg}$ ) and then Australian (30 to $400 \mu \mathrm{g} / \mathrm{kg}$ ), New Zealand and Russian ones (20 to $600 \mu \mathrm{g} / \mathrm{kg}$ ). The highest concentration of mercury was revealed in coal grades from Germany ( 700 to $1400 \mu \mathrm{g} / \mathrm{kg}$ ) with direct Polish and South African grades $(10$ to $1000 \mu \mathrm{g} / \mathrm{kg}$ ) right afterwards. Results of research studies carried out at the end of 20th century demonstrated that content of mercury in brown coal grades ranges from 81 to $1030 \mu \mathrm{g} / \mathrm{kg}$ with the average level of $323 \mu \mathrm{g} / \mathrm{kg}$ [5]. The least amount of mercury was found in coal from open pits of KWB Konin $(200-250 \mu \mathrm{g} / \mathrm{kg})$ whilst the most mercuryladen were coal grades from KWB Bełchatów $(416 \mu \mathrm{g} / \mathrm{kg})$.

The study [10] reports even higher content of mercury in brown coal grades from Polish mines, with the highest level of $2,600 \mu \mathrm{g} / \mathrm{kg}$ and the average of $1180 \mu \mathrm{g} / \mathrm{kg}$. But on the other hand, analyses of 29 samples taken from 6 largest Polish deposits [11] revealed the range of mercury concentration from 60 to $665 \mu \mathrm{g} / \mathrm{kg}$ with the average of $197 \mu \mathrm{g} / \mathrm{kg}$. At the same time content of mercury referred to the calorific value of fuel varied from 4.42 to $74.74 \mathrm{~g} \mathrm{Hg} / \mathrm{TJ}$ (21.38 g/TJ on average). Other studies completed at the Institute for Chemical Processing of Coal (IChPW) from 2009 to 2012 [12] made it possible to find out that content of mercury in brown coal grades ranged from 97 to $1300 \mu \mathrm{g} / \mathrm{kg}$, whilst the average concentration of mercury amounted to $360 \mu \mathrm{g} / \mathrm{kg}$ and was nearly fivefold higher that the respective content of mercury in hard coal $(73 \mu \mathrm{g} / \mathrm{kg})$.

The foregoing review of literature references clearly shows that results disclosed by individual authors significantly differ from each other. The broad range of results from determination of mercury content in coal grades is associated with many of factors. First and foremost it is extremely difficult to determine such low content of mercury in coal samples (trace analysis). Secondly, different research centres apply different analytic methods (AAS, CVAAS, CVAFS, ICP and other). The next premise lies in various weighs of coal samples and the sampling methods. Variable content of mercury in a coal deposit within the same coal mine as well as sampling locations (samples taken from faces, from haulage conveyors or averaged samples at the power plant) also cannot be neglected. All these reasons contribute to variations in determination results. 


\section{Experimental}

In 2013 a consortium was established by the Central Mining Institute (GIG), AGH University of Technology, Institute for Chemical Processing of Coal (IChPW) and Technical University of Częstochowa with the aim to launch the scientific and research project called BazaHg and financed by the National Centre for Research and Development (NCBiR). The project scope included comprehensive evaluation of mercury content in steam grades of hard coal (GIG in Katowice), coking grades of hard coal (AGH from Kraków) and brown coal (lignite) grades (IChPW from Zabrze). The achieved results made it possible to create a reliable and trustworthy database with specification of mercury contents in Polish fossils. The database shall enable reasonable and efficient management of mercury loads released into atmosphere from processes of fossil combustion and treatment.

To develop such a database with content of mercury in brown coal grades from Polish mines as many as 65 samples were taken from open pits on the area of Poland during the time period from 2014 to 2015 and parameters of these samples were determined. Each time samples with the weight of $50 \mathrm{~kg}$ were taken from open-pit faces. Then every single sample was disintegrated and averaged to obtain two representative analytic samples to determine physical and chemical properties of brown coal grades. The scope of investigations included:

- complete technical analysis (content of moisture, ash and volatile particles),

- complete elemental analysis (CHNS),

- determination of net calorific value and combustion heat,

- assay of chlorine and mercury content.

All analyses were carried out by the Accredited Laboratory of Fuels and Active Fuels operated by the Institute for Chemical Processing of Coal in Zabrze (accreditation from the Polish Centre of Accreditation, certificate number AB 081) pursuant to accredited standards and procedures summarized in Table 1.

Table 1. Applied accredited standards and procedures.

\begin{tabular}{|l|l|c|c|c|}
\hline \multicolumn{2}{|c|}{ Analysis } & Symbol & Standards/procedures & Error \\
\hline \multirow{3}{*}{$\begin{array}{l}\text { Technical } \\
\text { analysis }\end{array}$} & Total moisture, \% & $\mathrm{W}_{\mathrm{t}}{ }^{\mathrm{r}}$ & PN-80/G-04511 & 0.5 \\
& Analytical moisture, \% & $\mathrm{W}^{\mathrm{a}}$ & PN-G-04560:1998 & 0.1 \\
& Ash, \% & $\mathrm{A}^{\mathrm{a}}$ & PN-G-04560:1998 & 0.2 \\
& Volatile particles, \% & $\mathrm{V}^{\mathrm{daf}}$ & PN-G-04516:1998 & 0.17 \\
\hline \multirow{3}{*}{ Elemental } & Content of carbon, \% & $\mathrm{C}_{\mathrm{t}}{ }^{\mathrm{a}}$ & PN-G-04571:1998 & 0.6 \\
analysis & Content of hydrogen, \% & $\mathrm{H}_{\mathrm{t}}{ }^{\mathrm{a}}$ & PN-G-04571:1998 & 0.27 \\
& Content of nitrogen, \% & $\mathrm{N}^{\mathrm{a}}$ & PN-G-04571:1998 & 0.15 \\
& Content of oxygen, \% & $\mathrm{O}_{\mathrm{d}}{ }^{\mathrm{a}}$ & $\mathrm{z}$ obliczeń & 0.69 \\
\hline Heat of combustion, $\mathrm{kJ} / \mathrm{kg}$ & $\mathrm{Q}_{\mathrm{s}}{ }^{\mathrm{a}}$ & Q/LP/03/A:2011 & 83 \\
\hline Calorific value, $\mathrm{kJ} / \mathrm{kg}$ & $\mathrm{Q}^{\mathrm{a}}$ & Q/LP/03/A:2011 & 101 \\
\hline \multicolumn{2}{|l|}{ Chlorine content, \% } & $\mathrm{Cl}^{\mathrm{a}}$ & PN-G-04534:1999 & 0.017 \\
\hline \multicolumn{2}{|l|}{ Total mercury content, $\mu \mathrm{g} / \mathrm{kg}$} & $\mathrm{Hg}^{\mathrm{d}}$ & $\mathrm{Q} / \mathrm{LP} / 32 / \mathrm{A}: 2011$ & 28 \\
\hline
\end{tabular}

The content of $\mathrm{Hg}^{\mathrm{d}}$ was determined according to the accredited procedure $\mathrm{Q} / \mathrm{LP} / 32 / \mathrm{A}: 2011$. The analyses were carried out with use of the automatic Japanese analyzer MA-2 from Nippon Instrument Corporation (Fig. 2.) designed for mercury assay. The determination process consists in thermal decomposition $\left(850^{\circ} \mathrm{C}\right)$ of a sample under test and condensing of mercury on a gold trap with formation of amalgamate. Atomic mercury was then released from the collector by heating $\left(600^{\circ} \mathrm{C}\right)$ and its amount was 
assayed in an absorption cell with use of the CVAAS method, at the wavelength of $253.7 \mathrm{~nm}$. The error of the procedure is $28 \mu \mathrm{g} \mathrm{Hg} / \mathrm{kg}$.

Other determination procedures were carried out with use of the following instruments:

- thermogravimetric analyser TGA 701 from LECO with a full set of auxiliary equipment for determination of analytic moisture $\mathrm{W}^{\mathrm{a}}$ and content of ash $\mathrm{A}^{\mathrm{a}}$

- CHNS 628 instrument from LECO to determine content of carbon, hydrogen and nitrogen $\mathrm{C}_{\mathrm{t}}{ }^{\mathrm{a}}, \mathrm{H}_{\mathrm{t}}{ }^{\mathrm{a}}, \mathrm{N}^{\mathrm{a}}$

- SC-632 instrument from LECO to determine total content $\mathrm{S}^{\mathrm{a}}$ of sulphur $\mathrm{S}_{\mathrm{t}}{ }^{\mathrm{a}}$

- AC-350 or AC-500 calorimeters from LECO to determine calorific value and combustion heat $\mathrm{Q}_{\mathrm{s}}{ }^{\mathrm{a}}$ and $\mathrm{Q}_{\mathrm{i}}{ }^{\mathrm{a}}$

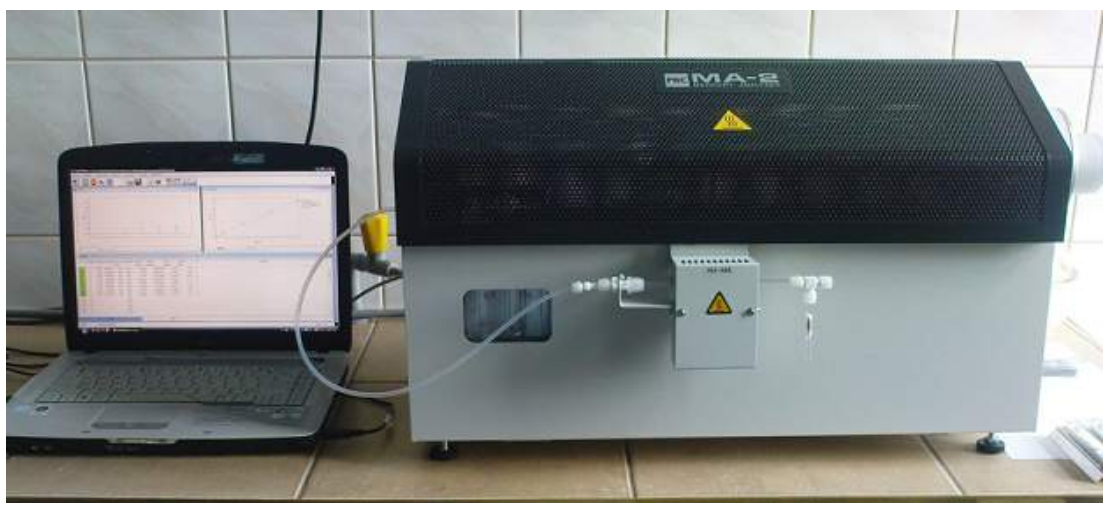

Fig.2. MA-2 mercury analyzer (NIC/Japan).

All completed measurements were subsequently used to set up a database with content of mercury in Polish mineable coal grades and products of processing thereof. Currently the database comprises 130 records related to brown coal, where each record stands for complete technical analysis (content of moisture, ash and volatile particles), complete elemental analysis (CHNS), content of chlorine and mercury as well as net calorific value and combustion heat. The database shall be consecutively supplemented with results of subsequent assays for brown coal samples.

\section{Results and discussion}

Table 2. Mercury content in Polish brown coal.

\begin{tabular}{|l|c|c|}
\hline Brown Coal Mine (KWB) & $\begin{array}{c}\text { Mercury content } \\
\boldsymbol{\mu g} \mathbf{~ H g} / \mathbf{k g}\end{array}$ & $\begin{array}{c}\text { Average mercury } \\
\text { content } \\
\boldsymbol{\mu g} \mathbf{~ H g} / \mathbf{k g}\end{array}$ \\
\hline KWB Bełchatów, Bełchatów open pit & $201-985$ & 499 \\
\hline KWB Bełchatów, Szczerców open pit & $175-922$ & 439 \\
\hline KWB Adamów, Adamów open pit & $251-619$ & 442 \\
\hline KWB Adamów, Koźmin open pit & $192-527$ & 339 \\
\hline KWB Turów & $144-601$ & 287 \\
\hline KWB Sieniawa & $44-310$ & 125 \\
\hline Average & $44-985$ & 345 \\
\hline
\end{tabular}

The analysis of mercury content in individual samples of brown coal (Table 2.) revealed that average content of mercury in Polish grades of brown coal makes $345 \mu \mathrm{g} \mathrm{Hg} / \mathrm{kg}$. The 
highest concentration of mercury was found for coal samples from Brown Coal Mine (KWB) in Bełchatów (the Bełchatów open pit) with the lowest content of $44 \mu \mathrm{g} \mathrm{Hg} / \mathrm{kg}$ recorded for coal samples from KWB Sieniawa. The comparison made for average content of mercury in coal samples taken from individual open pits revealed that the highest content of mercury occurred in coal samples from the Bełchatów open pit, i.e. $499 \mu \mathrm{g} \mathrm{Hg} / \mathrm{kg}$. Slightly lower concentration of mercury was recorded for the Szczerców open pit also operated by KWB Bełchatów $(439 \mu \mathrm{g} \mathrm{Hg} / \mathrm{kg}$ ) and from the Adamów open pit operated by KWB Adamów (442 $\mu \mathrm{g} \mathrm{Hg} / \mathrm{kg}$ ). The lowest level of mercury was recorded for coal from KWB Turów $(287 \mu \mathrm{g} \mathrm{Hg} / \mathrm{kg})$ and from KWB Sieniawa $(125 \mu \mathrm{g} \mathrm{Hg} / \mathrm{kg})$. The foregoing details, completed with information on coal consumption by individual power plants and multiplied by emission coefficients may serve for determination of mercury load released into the atmosphere from individual power plants and from the entire sector of power engineering in total. In addition, after taking account of combustion parameters and other figures standing for characteristics of fossils, one can precisely evaluate how much mercury is released into the atmosphere in flue gas from power plants.

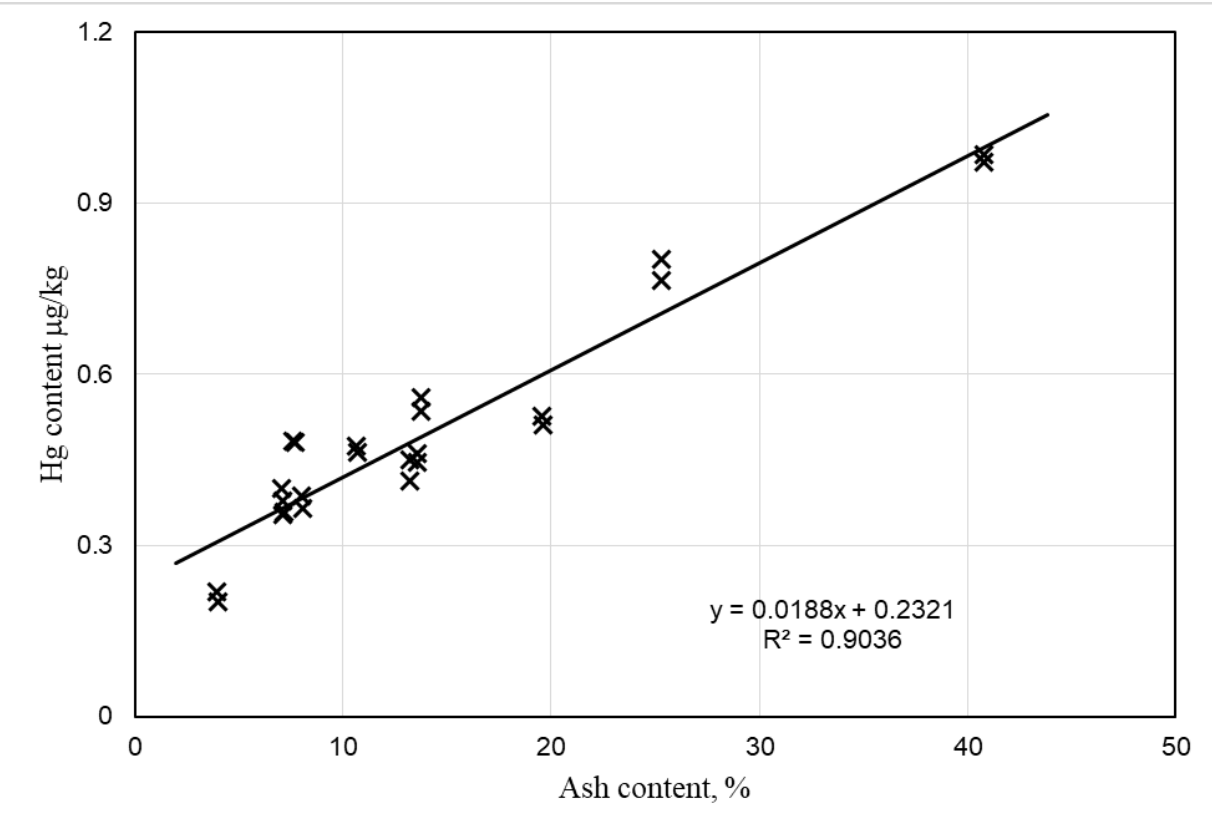

Fig.3. Exemplary dependence of mercury content on ash content. KWB Bełchatów.

Large amount of data enables also statistical analyses. The investigations were focused on correlations between individual physical and chemical parameters determined for fossils and including details on elementary composition or calorific value on one side and concentration of mercury on the other side. The calculations involved conventional analysis of regression (Statistica 6.0 from StatSoft). Sufficient amount of assay results enables also the statistical analysis with use of neural networks (Statistica Neutral Network from StatSoft). As a consequence, the following substantial relationships were established:

- content of mercury as a function of ash and volatile particles content,

- content of mercury as a function of sulphur content.

Examples of established correlations are shown in Fig. 3. and 4. 


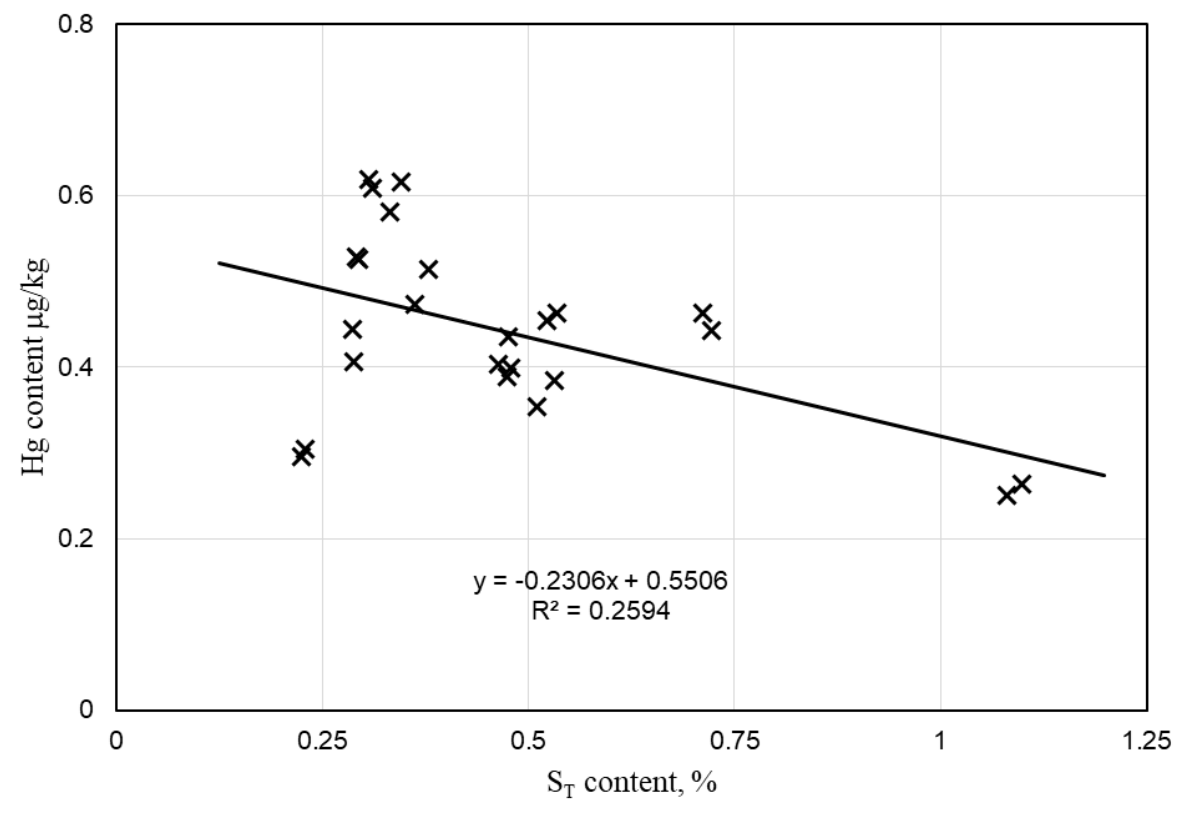

Fig.4. Exemplary dependence of mercury content on total sulphur content KWB Adamów.

\section{Summary}

Information disclosed in this study make up only a small portion of details comprised in the database described herein and set up for mercury content in domestic grades of brown coal. The developed database contains fully reliable and trustworthy knowledge about content of mercury in Polish fossils and enables reasonable and efficient management of combustion processes in the Polish sector of power engineering and associated release of mercury and its compounds into the atmosphere. The detailed analysis of coal grades shall also make it possible to predict emission of mercury from other processes associated with use of coal but different from simple combustion, for instance coal gasification, pyrolysis, coking technologies, production of activated charcoal and a long series of other products. It shall also enable Polish governmental organizations to cope with the exaggerated 'mercury problem' in Poland. The database with mercury contents shall be updated on current basis and shall be soon available on the project website.

The work was performed under the research project BazaHg no PBS2/A2/14/2013 founded in 2013-2016 by The National Centre for Research and Development, Poland.

\section{References}

1. National emission balance of $\mathrm{SO}_{2}, \mathrm{NO}_{x}, \mathrm{CO}, \mathrm{NH}_{3}, \mathrm{NMLZO}$, dust, heavy metals and TZO from 2014 - 2015 in the SNAP classification. Synthetic report. KOBiZE Publishing House, Warszawa, 2017

2. A. Pietraszewski, Węgiel Brunatny 2, 4 (2015)

3. L. Sloss, Mercury emissions and effects-the role of coal. IEAPER/19, London, England, August 1995 
4. A. Głodek, J. Pacyna, Atmospheric Environment 43, 5668 (2009)

5. I. Bojakowska, G. Sokołowska, Biuletyn PIG 394, 5 (2001)

6. K. Wojnar, J. Wisz, Energetyka 4, 280 (2006)

7. U. Lorenz, Z. Grudzinski, Gospodarka Surowcami Mineralnymi 24, 1271 (2008)

8. S. Tewalt, L. Bragg, R. Finkelman, Mercury in U.S. Coal. Abundance, distribution and modes of occurrence, U.S.Geological Survey; Fact Sheet 095, 2001

9. E. Pacyna, J. Pacyna, J. Fudała, E. Strzelecka-Jastrząb, S. Hławiczka, D. Panasiuk, Sci. Tot. Environ. 370, 147 (2006)

10. B. Bielowicz, Gospodarka Surowcami Mineralnymi 29, 47 (2013)

11. J. Gołaś, A. Strugała, P. Burmistrz, T. Dziok, A. Rozwadowski, The content of mercury in Polish coal and products of their enrichment. Mercury emission and possibilities of reducing it in the Polish energy sector, AGH Publishing House, Kraków 2015

12. E. Misztal, T. Chmielniak, I. Mazurek, The content of mercury in fuels used in the Polish energy sector and possibilities of its reduction by means of thermal treatment before combustion, III International Scientific Conference, Mercury in Environment, Gdynia, May 8-10, 2013 